\title{
DETERMINATION THE BIOLOGICAL EFFECTIVENESS PYOCYANIN DYE PRODUCED FROM BACTERIA PSEUDOMONAS AERUGINOSA
}

\author{
BUTHINA ABDULHAMEED ABDULLAHA \\ Assistant Professor of Pharmacology, Department of Physiology and Pharmacology
}

Received: 31 March 2016; $\quad$ Accepted: 30 April 2016

\begin{abstract}
This study was conducted from the beginning of the month November to the end of the month of December 2013. The sample was obtained from the Faculty of Science / University of Tikrit, the sample has been confirmed by using biochemical tests. And also conducted extracted DNA from bacteria P.aeruginosa to know the gene responsible for the production of pyocyanin and an electrophoresis that has led to the emergence of packages specific prefixes that indicate the presence of specific gene for pyocyanin in chromosome of P.aeruginosa. The results showed that isolated sample has produced the highest amount of the pyocyanin $(23.41 \mu \mathrm{g} / \mathrm{ml})$. We studied the effect of pyocyanin on the growth of some types of bacteria and the results showed that the pyocyanin an effective impact on the inhibition of the growth of bacterial species including, Escherichia coli, E.faecalis Staphylococcus aureus, Salmonella typhi, and also had an impact on bacteria P.aeruginosa.
\end{abstract}

Key words: Biological, Effectiveness, Pyocyanin Dye Produced, Pseudomonas, Aeruginosa.

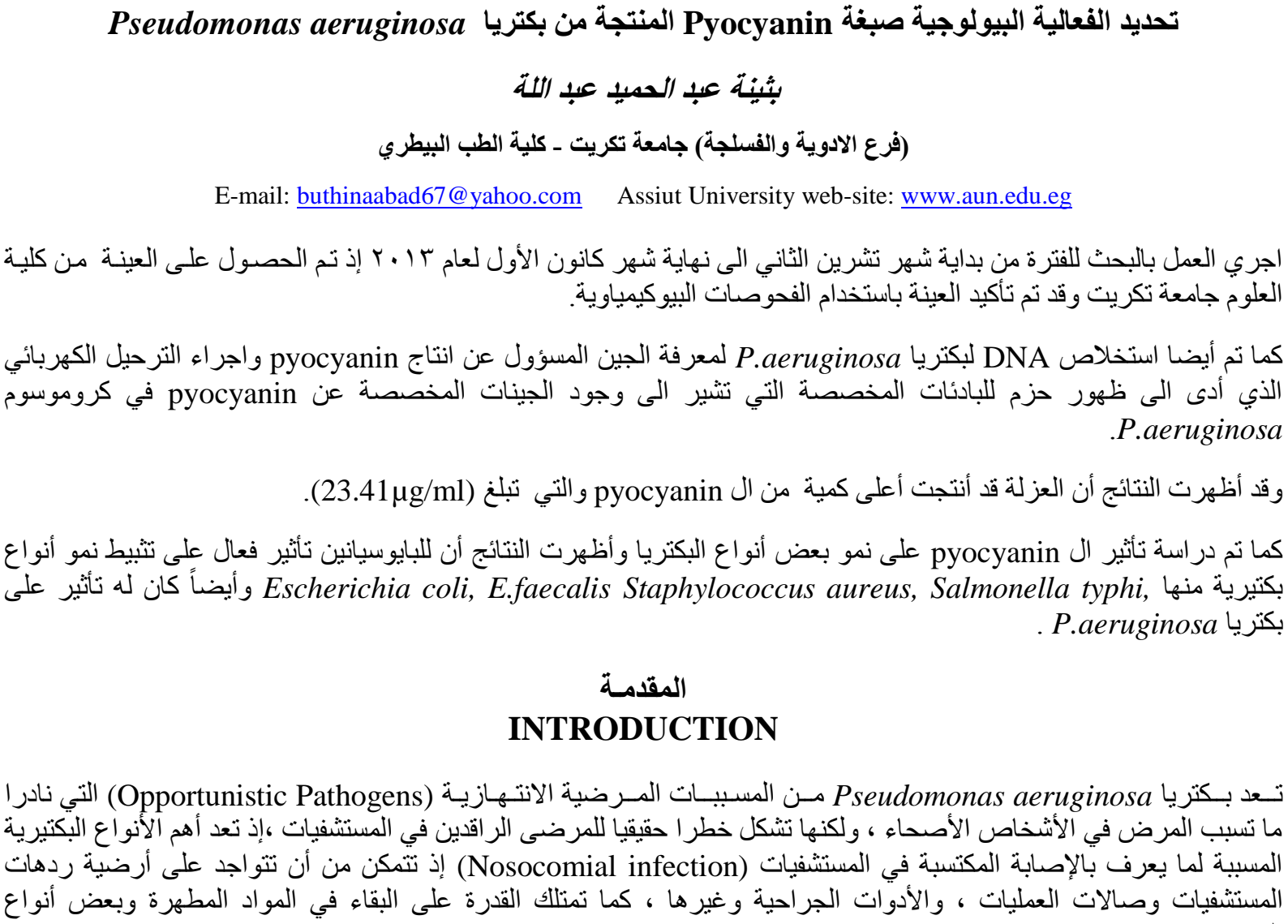

المعقمات (Greenwood et al., 2007).

Corresponding author: BUTHINA ABDULLAHA

E-mail address: buthinaabad67@yahoo.com

Present address: Assistant Professor of Pharmacology, Department of Physiology and Pharmacology 


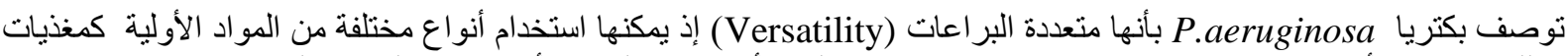

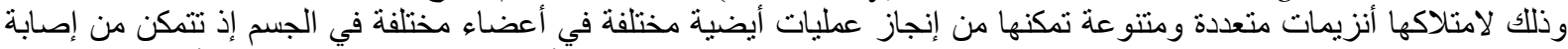

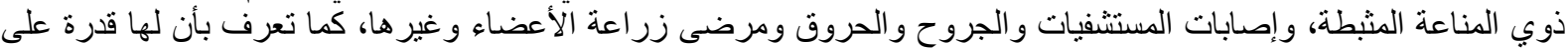
التكيف للظروف غير الطبيعية ومنها.

(Balch and Smith, 1994; Lyczak et al., 2000 and امتلاكها مستوى عالياً من المقاومة لمعظم أنو اع المضادات الحيوية (19) Doring, 1993)

تتصف بكتريا P.aeruginosa بأنها من الميكروبات الثائعة و الو اسعة الانتشار (Ubiquitous) إذ توجد في الترب و والمياه وكفلورا

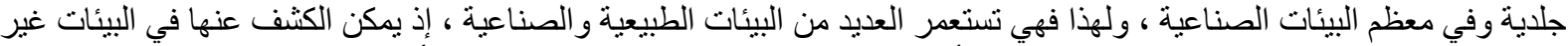

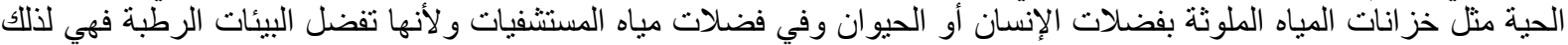

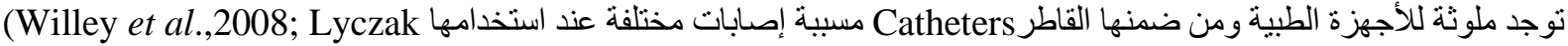
et al., 2000)

تتمكن سلالات P.aeruginosa من إنتاج أنو اع من الصبغات وهي صبغة البايو سيانين Pyocyanin التي تتصف بأنها صبغة زرقاء

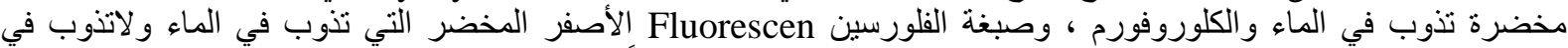

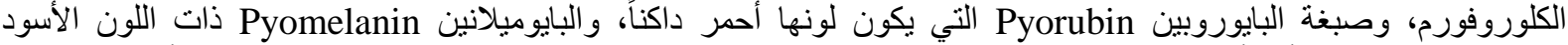

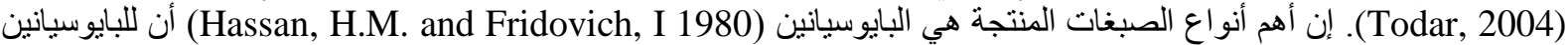
فعالية مضادة لأنواع بكتيرية وفطرية مختلفة (Antibacterial) وهو فاتل لأنو اع عديدة من البكتريا (bacteriocidal) منها :-

Escherichia coli,Staphylococcusaureus

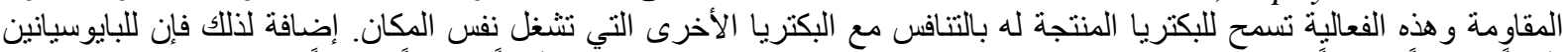

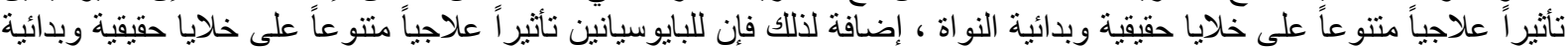

النواة (Saha et al., 2008).

\section{المواد وطر ائق العمل \\ MATERIALS AND METHODS}

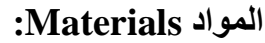

الأدوات والأجهزة المختبرية Equipments and apparatus:

\begin{tabular}{|c|c|c|}
\hline الشركة المصنعة وبلا المنشأ & اسم الجهاز & 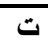 \\
\hline Gallenkamp/England & الموصدة Autoclave & 1 \\
\hline Hettich EBH.20/German & جهاز الطرد المركزي Centrifuge & 2 \\
\hline Memmert/Germany & حاضنة Incubator & 3 \\
\hline Olympus/Japan & مجهر ضوني Microscope & 5 \\
\hline Hanna/Porlugal & مقياس الرقم الهيدروجيني pH meter & 6 \\
\hline Hangping JA 1003/Japan & ميز ان كهربائي حساس Electric balance & 7 \\
\hline Cecil/France & عداد المطياف الضوئي spectrophotometer & 9 \\
\hline Germany & أور اق ترشيح Millipore filter(0.45) & 11 \\
\hline Sony/Japan & كامبر ا رقمية Digital Camera & 13 \\
\hline Ishtar/Iraq & تلاجة Refrigerator & 14 \\
\hline Jlassco (India) & flasks Volumertric دوارق حجمية & 15 \\
\hline
\end{tabular}

Chemicals and biological materials المواد الكيمياوية والبايولوجية

المواد الكيمياوية :جدول (3-2) المواد الكيمياوية المستخدمة في الدراسة

\begin{tabular}{|c|c|c|}
\hline المنشأ (Company) & المواد الكيمياوية Materials & $ت$ \\
\hline Chloroform & Chloroform كلوروفورم & 1 \\
\hline BDH/England & حامض الهيدروكلوريك & 2 \\
\hline BDH/England & K2SO4 كبريتات البوتاسيوم & 3 \\
\hline BDH/England & كلوريد المغنيسيوم MgCl2 كلوم & 4 \\
\hline Microbiologie/ Germany & بيتونPeptone & 5 \\
\hline
\end{tabular}




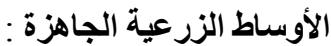

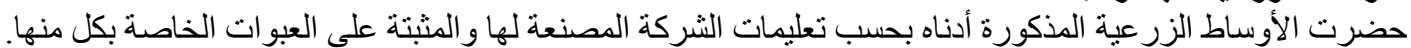
جدول (3-3) الأوساط الزر عية و الغرض من استخدام كل الوسط.

\begin{tabular}{|c|c|c|c|}
\hline الغرض من استخد/مه & الشركة المصنعة وبلد المنشأ & الوسط الزرعي & $ت$ \\
\hline للتحري عن قابلية البكتريا على تحلل الدم وتحديد نوع & Himedia/India & وسط الدم الصلب Blood agar base & 1 \\
\hline لتنمية البكتريا السالبة لصبغة جر ام وقابليتها على تخمير & Himedia/India & $\begin{array}{c}\text { وسط الماكونكي } \\
\text { Mac Conkey agar }\end{array}$ & 3 \\
\hline لاختبار حساسية البكتريا للمضادات الحيويه. & Oxoid/England & $\begin{array}{l}\text { وسط مولر هنتون الصلب } \\
\text { Muller Hinton agar }\end{array}$ & 4 \\
\hline 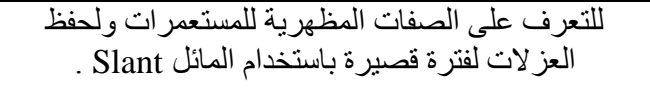 & Himedia/India & الوسط المغذي الصلب & 5 \\
\hline لتنشيط البكتريا وتحضير التخافيف البكتيرية. & Himedia/India & $\begin{array}{c}\text { الوسط المغذي السائل } \\
\text { Nutrient broth }\end{array}$ & 6 \\
\hline للتحري عن قابلية البكتريا في أنتاج أنزيم اليوريز Urease & Himedia/India & $\begin{array}{c}\text { Urea agar وسط أجار اليوريا الأساس } \\
\text { base }\end{array}$ & 7 \\
\hline للكثف عن قابلية البكتريا على استهلاك السترات كمصدر & Himedia/India & $\begin{array}{c}\text { Simmon وسط سيمون ستريت } \\
\text { Citrate } \\
\end{array}$ & 8 \\
\hline
\end{tabular}

Antibiotic discs المضادات الحيوية

جاول (4-3): المضادات الحيوية المستخدمة في اختبار حساسية عزلات بكتريا P.aeruginosa

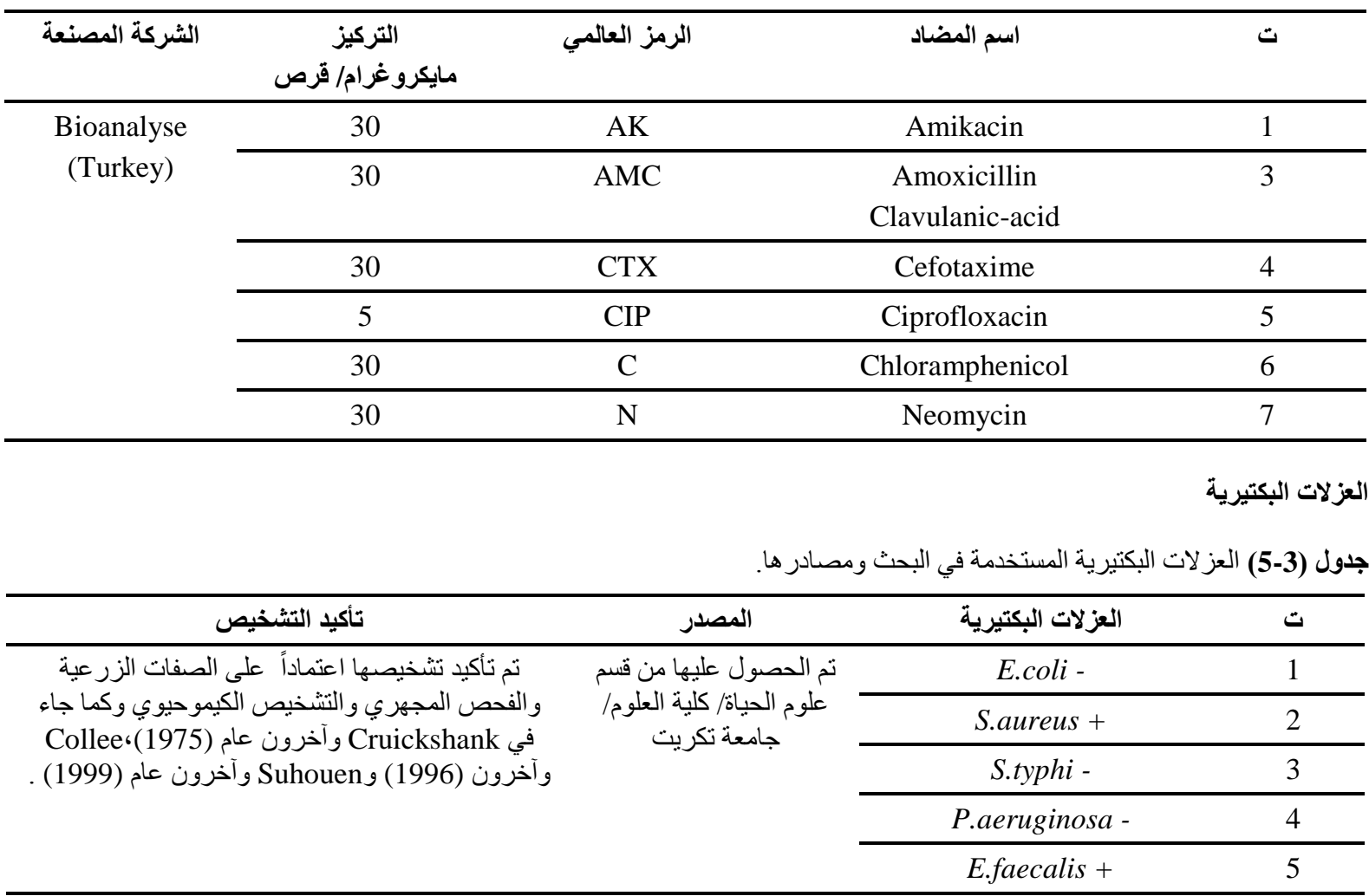


وسط أجار الدم الصلب Blood Base Agar

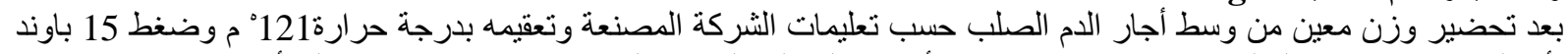

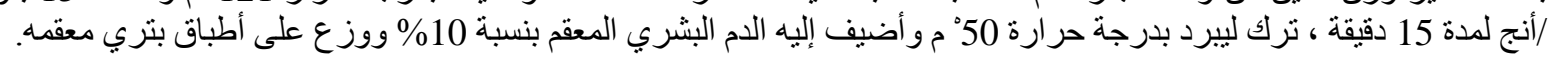

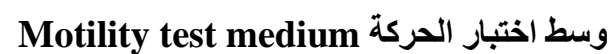
استخدم للتحري عن قابلية البكتريا على الحركة ،حضر بإضافة 0.5 \% من من الاجار ـ أجار إلى الوسط المغذي السائل ،عقم بالموصدة

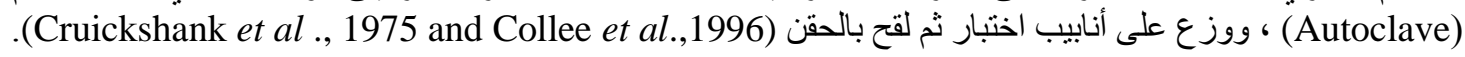

وسط اليوريا الصلب urea media

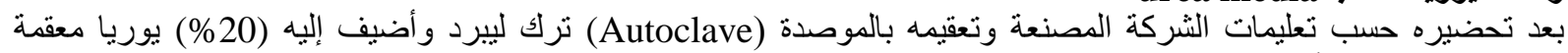

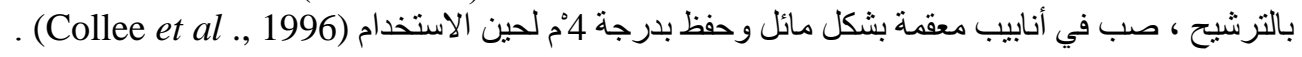

MacConkey agar وسط ماكونكي أجار

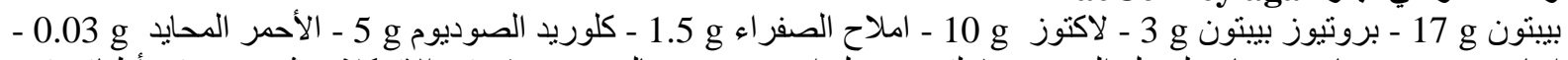

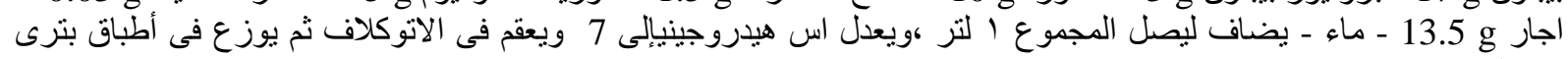

معقمة.

وسط Pseudomonas broth (PB)

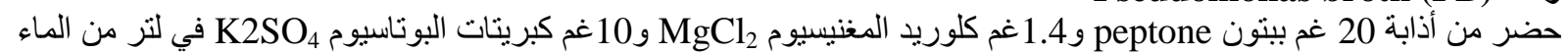

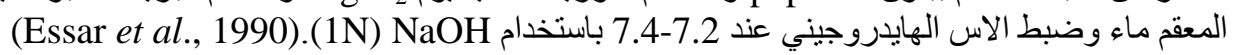

وسط اختبار الأندول Indol test

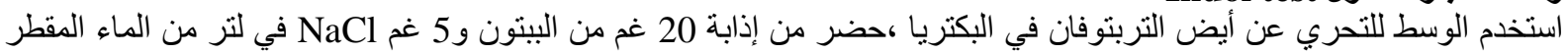

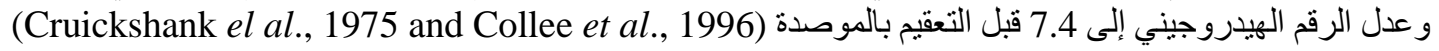

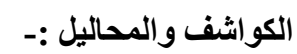

كاشف كتاليز Catalase

استخدم للتحري عن إنتاج البكتريا لأنزيم Catalase، وقد حضر بتركيز3 \% م (Collee et al., 1996)

كاشف الاوكسيديز Oxidase

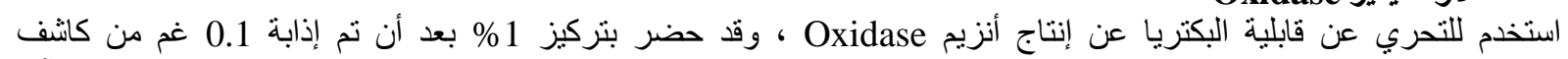
في 10مللتر من الماء الدقطر وحفظ في فنينة معتمة، واستعمل آنيا

.(Collee et al., 1996)

كاثشف كوفاك

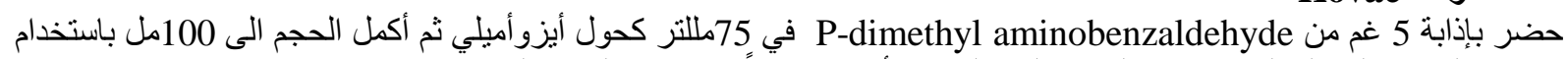
حامض الهيدروكلوريك المركز ببطء ليصبح لون الكاثف أصفر شاحباً وحفظ في الثلاجة لحين الاستخدام .(Cruickshank et al., 1975 and Collee et al., 1996)

كاثف المثيل الأحمر Methyl Red (MR) حضر بإذابة 0.1 غم من المثيل الأحمر في 300 مل كحول أنثلي (95\%) ثم أكمل الحجم إلى 5.0مل باستخدام ماء مقطر (Cruicshank et al., 1975 and Collee et al., 1996)

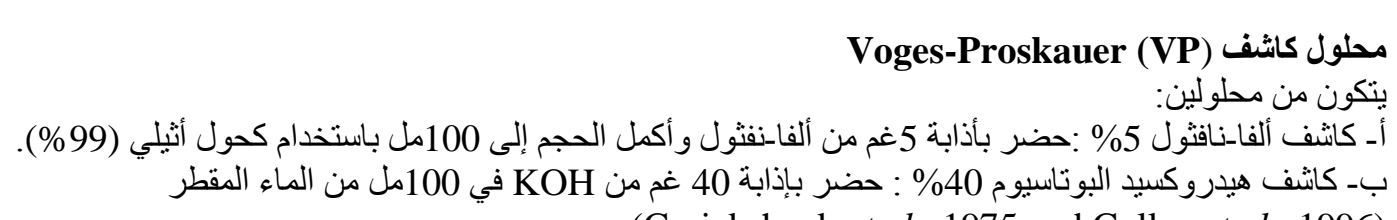

(Cruickshank et al., 1975 and Collee et al., 1996)

Sterilization التعقيم التعقيم الرطب (Autoclaving) wet sterilization )

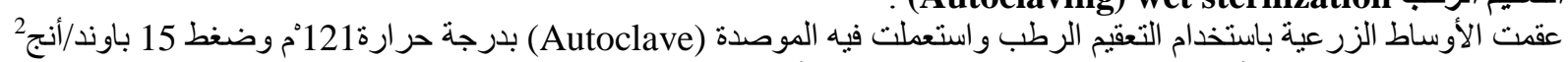

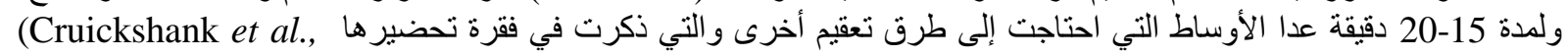




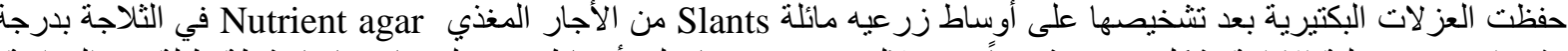

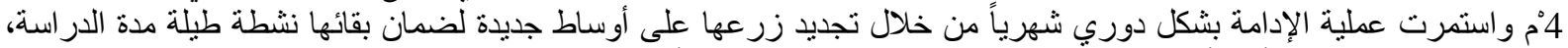

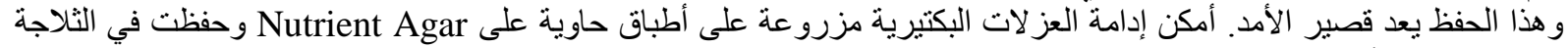
بدرجة 4 مذر لعدة أسابيع.

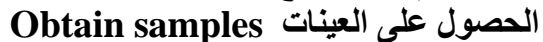
تم الحصول على العينات من كلية العلوم جامعة تكريت وكانت معزولة بشكل تام.

زرع العينات

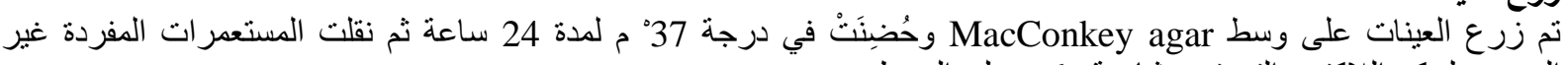
المخمرة لسكر اللاكتوز التي تبدو شاحبة pale على الوسط.

التشخيص Identification

تم تشخيص العزلات النامية باستخدام الاختبار ات المظهرية والمجهرية والكيموحيوية وفق ماورد في Cruickshank و آخرون ، Collee ، (1975)

نم إجر اء الاختبار بأخذ مستعدرة مفردة باستخدام الناقل (Loop) ومزجت مع بضع قطر ات من كاشف

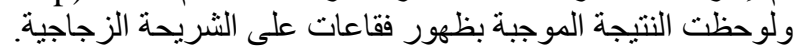

(Cowan and Steel's.1993)

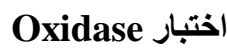

تم إجراء الاختبار بوضع بضار بهع قطرات من كاثف Oxidase على ورقة ترشيح ثم نقلت مستعدرة مفردة باستخدام عود خشبي

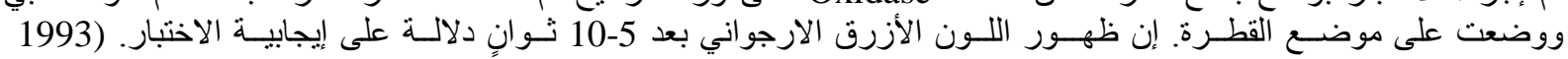
(Cowan, and Steel's

IMViC اختبارات Indol test اختبار الأندول-A

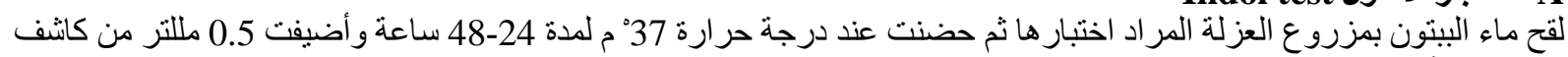
،عدّت نتيجة الاختبار موجبة عند ظهور حلقة حمر اء على سطح الوسط ـ (Cowan and Steel's. 1993).

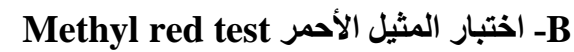

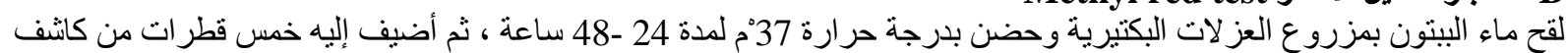
(Cowan and Steel's. 1993). المثيل الأحمر، إنَّ تحول الوسط إلى اللون الأحمر دلالة على النتيجة المونة

Voges Proskauer test اختبار -C لقح ماء الببتون بمزروع العزلات البكتيرية وحضن بدرجة حرارة 37مة لمدة 24 ساعة ، ثم أضيف 1مل من كانشف هيدروكسيد

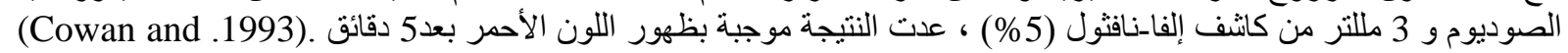

Steel's

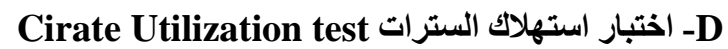
لقح وسط أكار سيمون السترات الحاوي على مات مادة بروموثايمول الزرقاء لمدة 24 ساعة. عُدّت النتيجة موجبة من خلال تغير لون الوسط من الأخضر إلى الأزرق. (Cowan and Steel's.1993)

Motility test اختبار الحركة

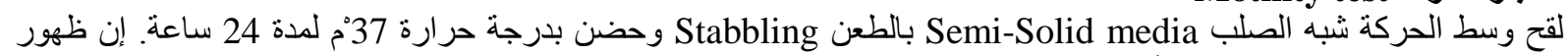
منطقة ضبابية حول خط الطعن دليلّ على النتيجة الموجبة. (Cowan and Steel's 1993)

Urease test اختبار إنتاج اليوريز

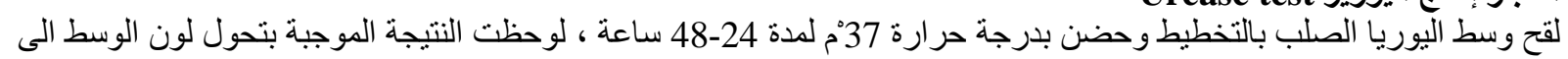
(Cowan and Steel's1993). الورديط اختبار حساسية البكتريا للمضادات الحيوية: *خُبَّرَ وسط مولر هنتون الصلب وصنب في أطباق معقمة بحيث لا يقل ارتفاع الوسط عن 4 ملمتر وثُرك ليتصلب. 


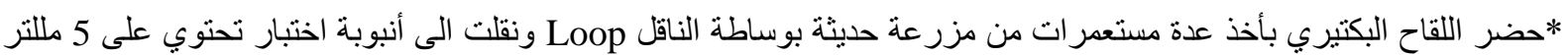

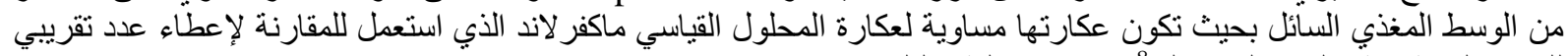

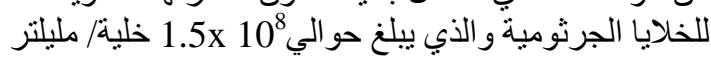

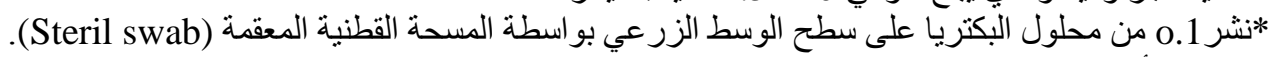

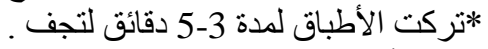
*قنلت أقراص الاطباد المدات الحيوية المذكورة في الجدول رقم (3-4) باستخدام ملقط معقم ووزعت على الأطباق المزروعة بالبكتريا

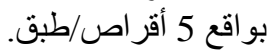

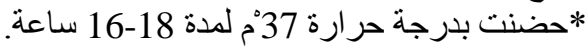
.(Clinical and Laboratory Standards Institute [M7-A7], 2006

إنتاج و استخلاص وتنقية البايوسيانين:إنتاج صبغة البايوسياتين

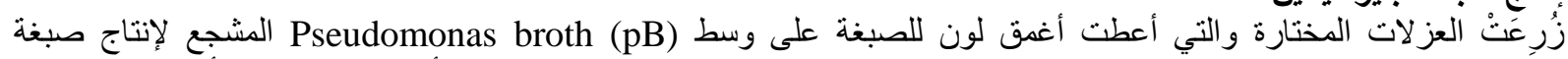

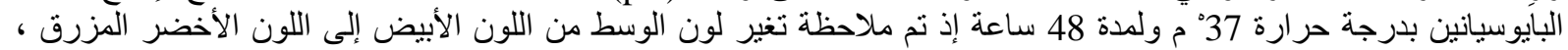

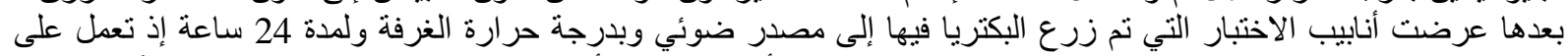

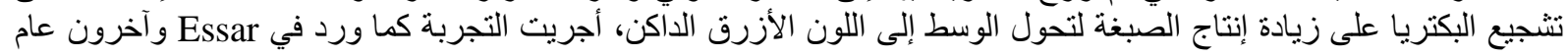

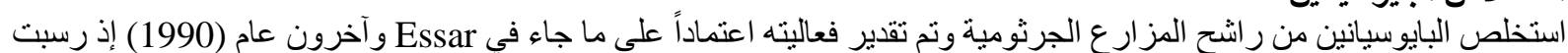

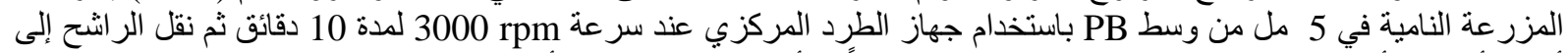

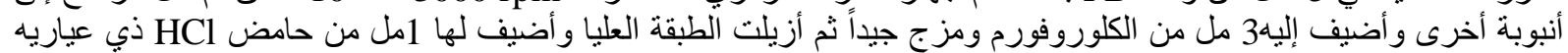

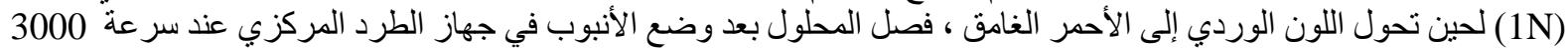

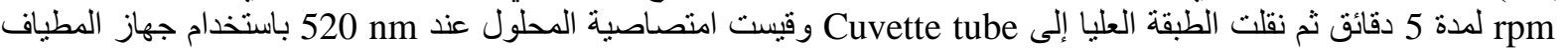
الضوئي Spectrophotometer. ثم تم حساب التركيز والذي يعبر عن كل مايكروغرام من البايوسيانين المنتج/مليلتر من راشيح

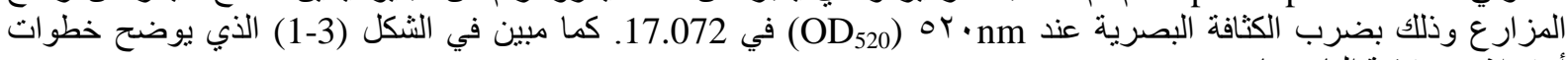
أستخلاص وتنقية البايوسيانين.

تنقية البايوسيانين Purification of pyocyanin

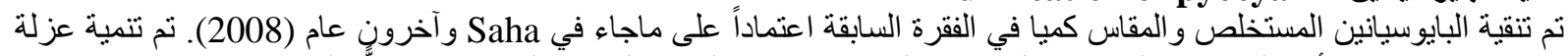

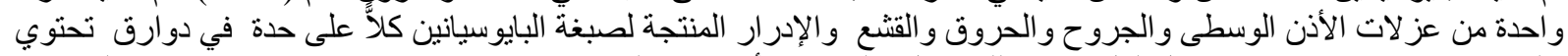

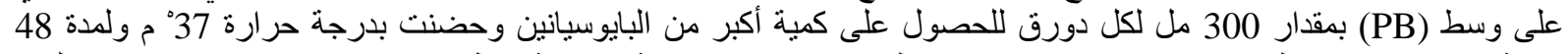

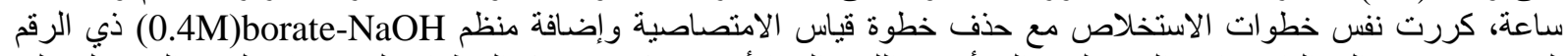

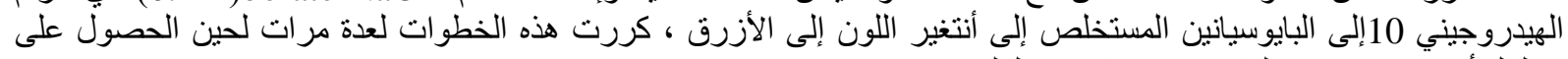
محلول أزرق صافٍ من البايوسيانين مذابا في الكلوروفورم.

و لإنتاج أكبر كمية من صبغة البايوسيانين زرعت هذه العزلات على على وسط (Pseudomonas broth (PB) الذي يحوي في تركيبه

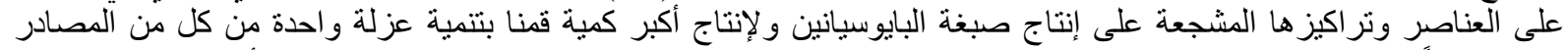

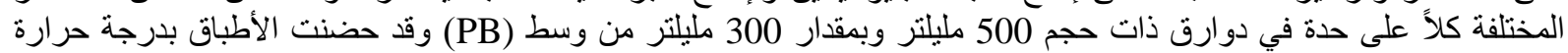

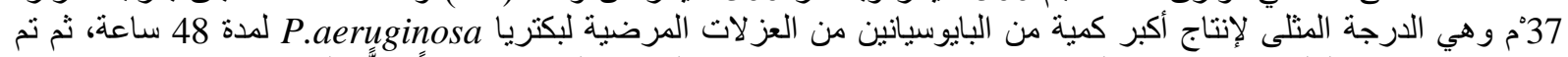

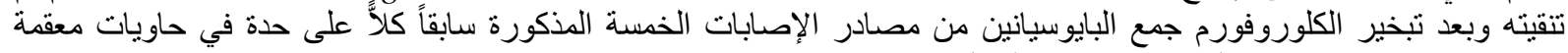
ونظيفة وحفظ بدرجة 20-نم لحين الاستخدام، الثكل (3-1-1) .

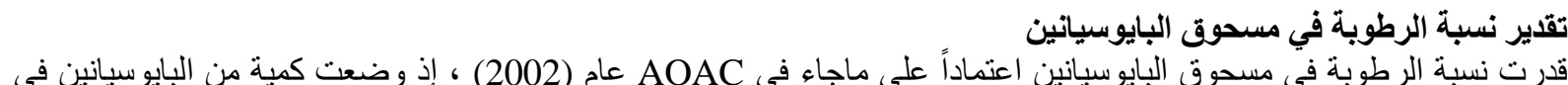

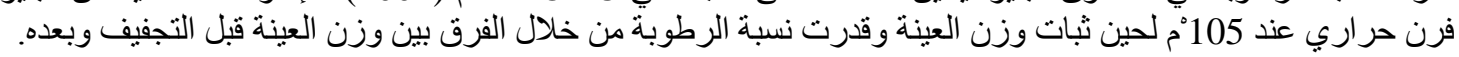

تقييم فعالية البايوسياتين كمضاد مايكروبي مختبرياً

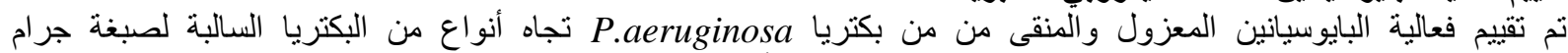

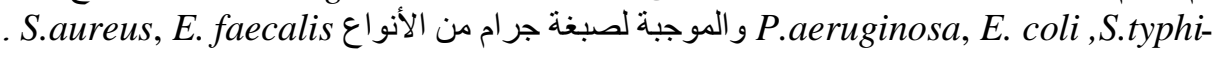

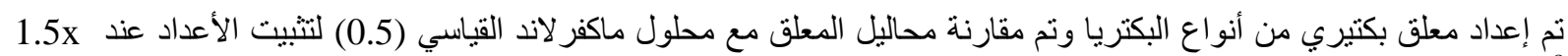

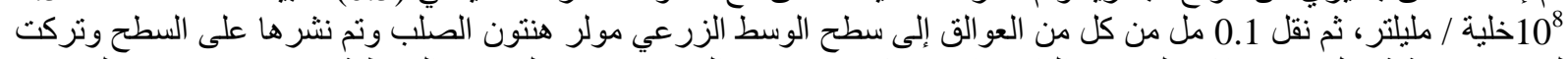

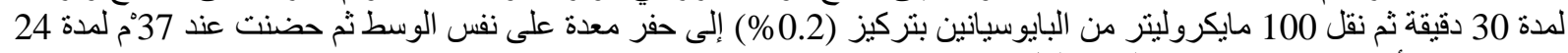
ساعة وبعدها أخذ قياس قطر منطقة التثبيط لكل نوع. 


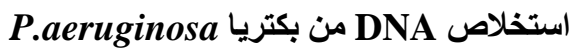

• عمل طرد مركزي مالا يزيد عن ب ملليتر من 40rum بقوة ( 400xg ) لمدة 10 دقائق بدرجة حرارة الغرفة • سحب الطبقة العليا و اهمالها . •

• اضافة 100 مايكرو ليتر من محلول الاذابة (TE buffer) ثم نمرر النماذج على جهاز الدوام لإكمال المزج واذابه الاجسام الصلبة اصنة

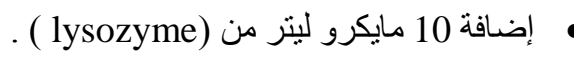

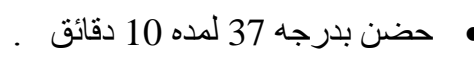

• اضافه 100 مايكرو ليتر من (BTL Buffer) و 20 مايكرو ليتر من (Voroteinase k) ثم مزج بجهاز الدوام (Vortex)

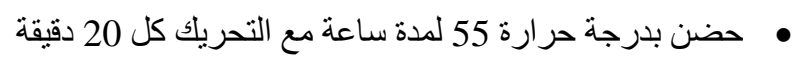

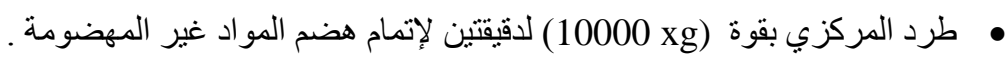

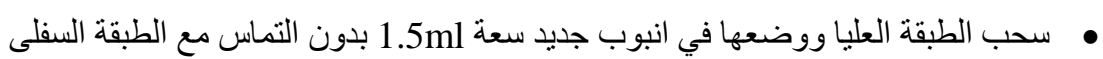

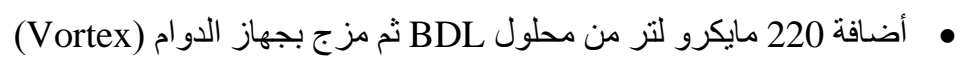

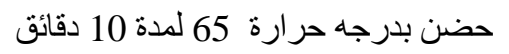
اضافة 220 مايكرو ليتر من الايثانول (96_100\%) ثم مزج بالدوار لمدة 20 ثانيه بأعلى سرعه لإتمام المزج واذا ظهرت فقاعات يتم سحبها بالماصة الدقيقة

• وضع (Hi Bind DNA mini column) (انابيب خاصة بالطقم الجاهز والتي تحتوي على مرشح filter) في انابيب سعه 2 (H) (collection tube) $\mathrm{ml}$

$$
\begin{aligned}
& \text { • نقل النماذج من انبوب ml } 1.5 \text { الى الانابيب الخاصة بالطقم } \\
& \text { • طرد مركزي بقوة (10000 xg) لمدة دقيقة واحدة }
\end{aligned}
$$

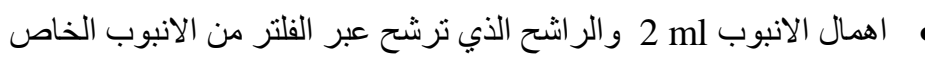

$$
\begin{aligned}
& \text { • وضع الانبوب الخاص في انبوب ml } 2 \text { جديد }
\end{aligned}
$$

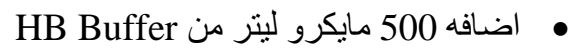

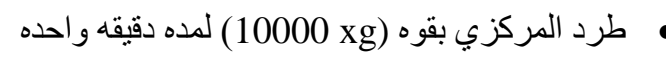

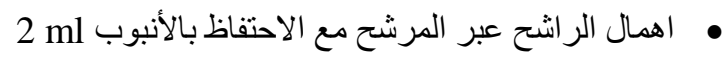
• اضافه 700 مايكرو ليتر من محلول الغسل ثم طرد مركزي بقوة (10000 xg) لمدة دقيقة واحدة

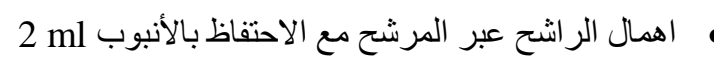

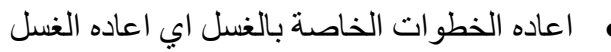
• وضع الانابيب الفارغة الخاصة بالDNA بجهاز الطرد المركزي بسر عه (10000 xg) لمدة 2 دقيقه لتجفيف الانابيب • وضع الانابيب في انابيب سعه 1.5 مل جديده

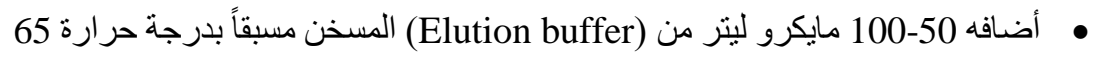

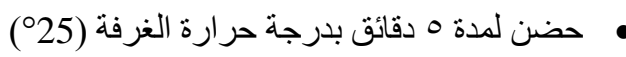

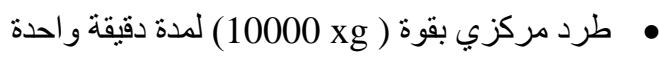

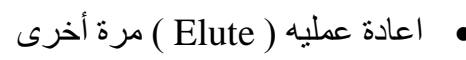
حفظ Eluted DNA بدرجه حراره - El عزدة 20

تقدير تركيز DNA المستخلص ونقاوته: تم تقدير تركيز الـ DNA عن طريق وضع ا مايكرو ليتر من العينة المستخلصة في جهاز (Nano drop) وتراوحت نقاوة العينة من -1.82) 
البادئات المخصصة Specific Primers

\begin{tabular}{|c|c|}
\hline البادئ المخصص & الوزن الجزيئي \\
\hline $\begin{array}{c}\text { Phenazine biosynthetic operon (phzABCDEFG) PHZP F 5' } \\
\text { CCGTCGAGAAGTACATGAAT 3' PHZP R 5' } \\
\text { CATAGTTCACCCCTTCCAG 3' }\end{array}$ & $448 \mathrm{bp}$ \\
\hline $\begin{array}{l}\text { Phenazine - specific methyltransferase(phz M) } \\
\text { PHZP F 5' AACTCCTCGCCGTAGAAC 3' } \\
\text { PHZP R 5' ATAATTCGAATCTTGCTGCT }\end{array}$ & $313 \mathrm{bp}$ \\
\hline \begin{tabular}{c}
\multicolumn{2}{c}{ Flavine containing Monooxygennase (phzS) } \\
PHZP F 5' TGCGCTACATCGACCAGAG 3' $\quad$ PHZP R 5' \\
CGGGTACTGCAGGATCAACT 3'
\end{tabular} & $664 b p$ \\
\hline
\end{tabular}

(Polymerase chain reaction) PCR جهاز

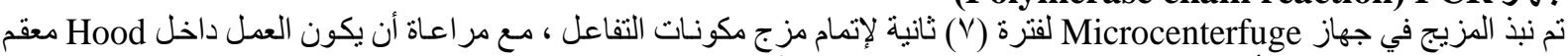
و وارتداء القفاز ات ووضع الأنابيب داخل عبوة تلج ثم تطبيق البرنامج الآتي:

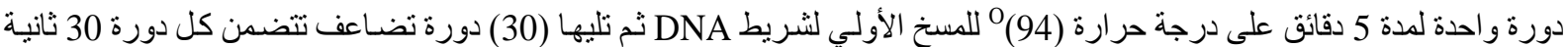

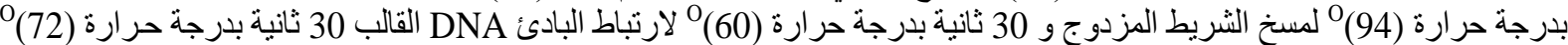

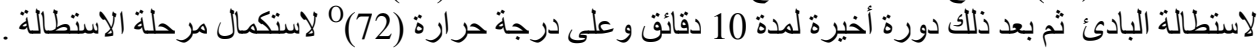

\section{النتائج والمناقثة \\ RESULTS AND DISCUSSION}

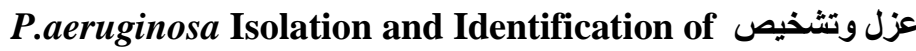

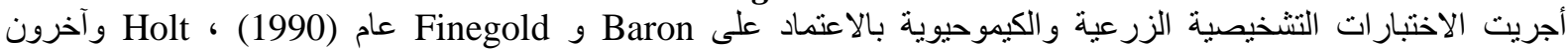

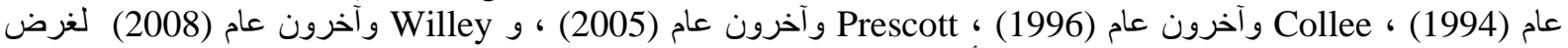

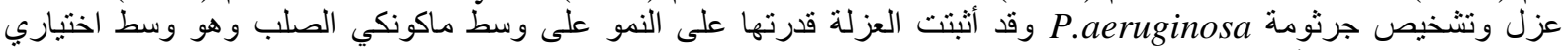

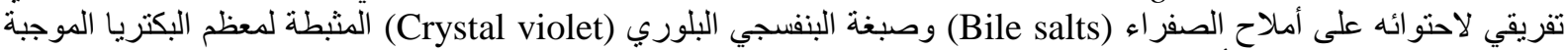

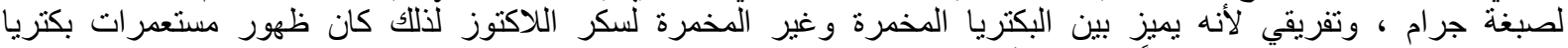
P.aeruginosa

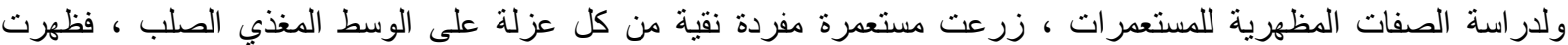

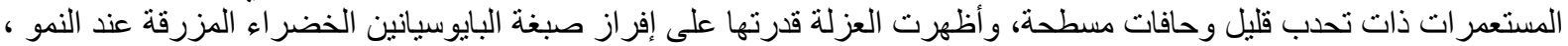

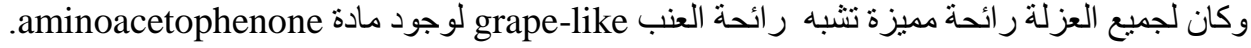

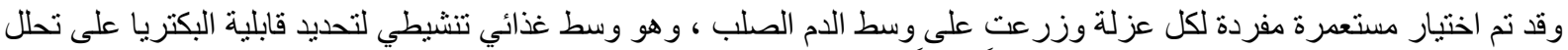

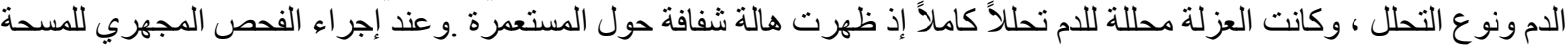
البكتيرية المصبو غة بصبغة جر ام، ظهرت بكتريا P.aeruginosa سالبة لهذه الصبغة ولفي شكل عصيات مفردة أو سلاسل قصيرة.

وقد أظهر التشخيص أن العزلة أعطت نتيجة موجبة لاختبار إنتاج الأوكسيديز Oxidase وهو من الاختبارات التشخيصية المهمة

كما أظهرت فحصاً موجباً لاختبار الكتاليز Catalase. كما وأجرية فحص IMViC وكانت النتيجة سالبة اختبار الأندول Indole 
وعند إضافة الكاثف كانت النتيجة سالبة لاختبار فوكس بروسكور ، وهو اختبار يستخدم للتحري عن قابلية البكتريا للتخمر الجزئي لسكر الكلوكوز، إن العزلة كانت سالبة لهذا الاختبار.

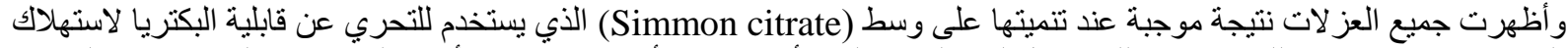
السترات كمصدر وحيد للكاربون، وذللك بتحول لون لألون الوسط إلى الأزرق وكما أوضحت نتيجة لأنزيم اليوريز ان النتيجة كانت الموجية

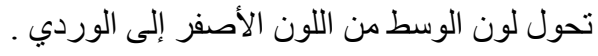

3- 3- إنتاج و استخلاص وتنقية البايوسيانين

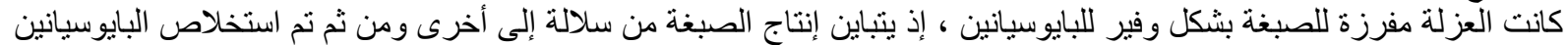

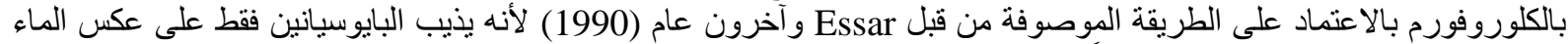

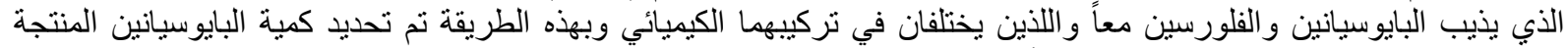

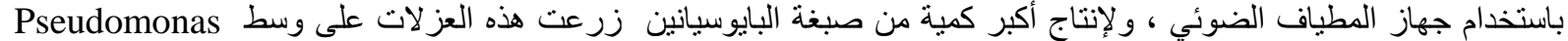
broth (PB)

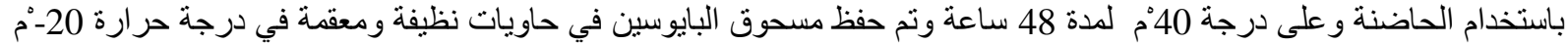

لحين استخدامه.
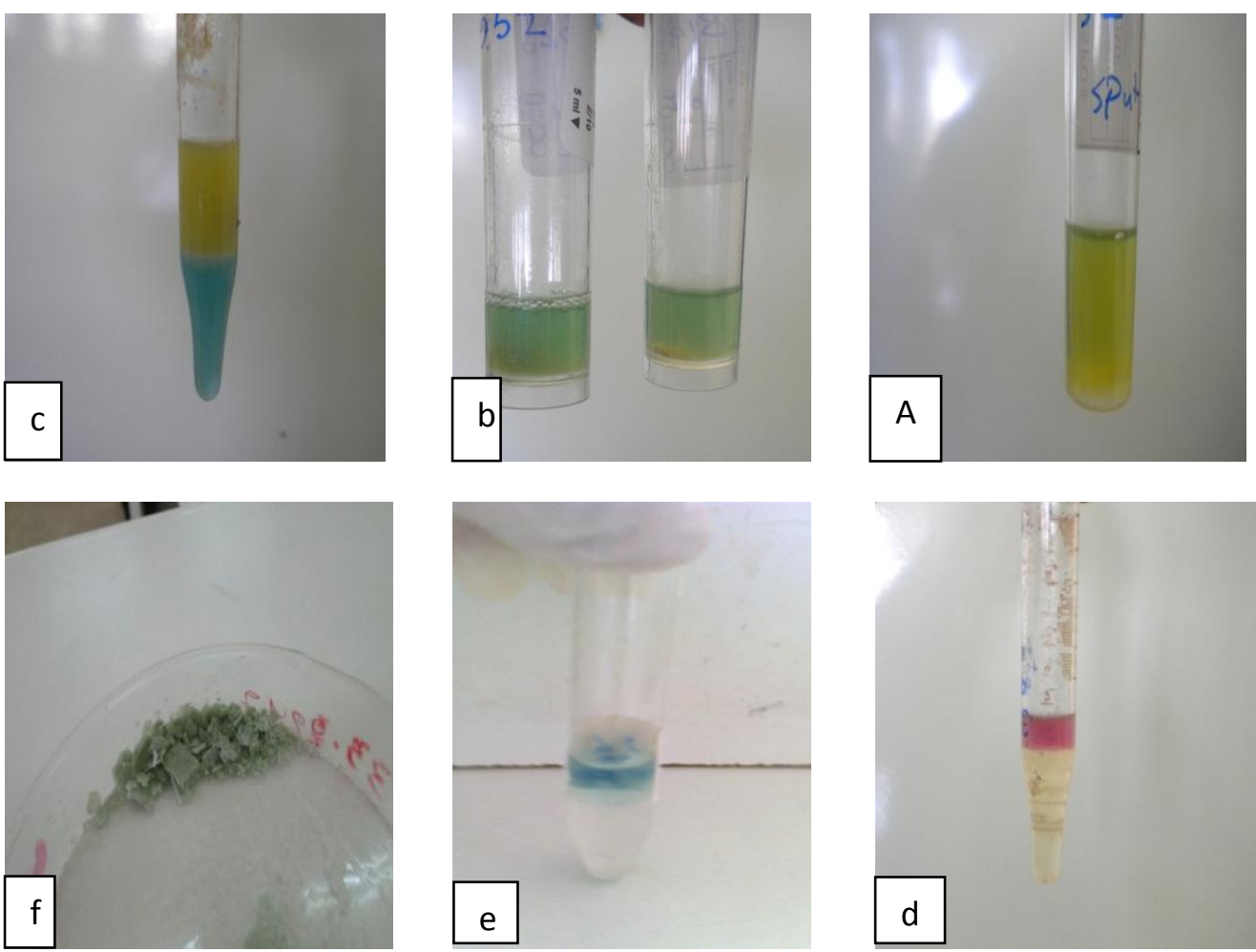

حساسية العزلة للمضادات الحيوية :-

استخدم اختبار انتشار الأقراص القياسي لتحديد حساسية بكتريا P.aeruginosa تجاه أنواع متعددة من المضادات الحيوية وقورنت

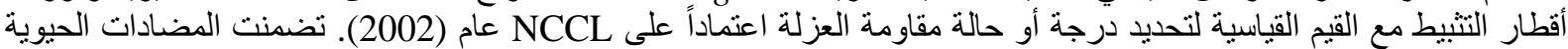
Amoxicillin-Clavulanicacid (AMC), Cefotaxime (CTX), Ciprofloxacin (CIP), الأنواع الآعة الآتية:Chloramphenicol (C) Neomycin (N),

بينت النتائج كما في الصورة (4-2) أن عزلة البكتريا كانت حساسة لمضاد Ciprofloxacin .

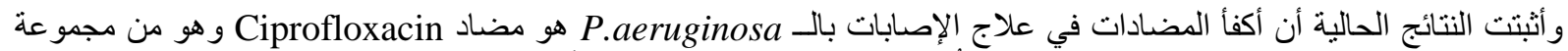

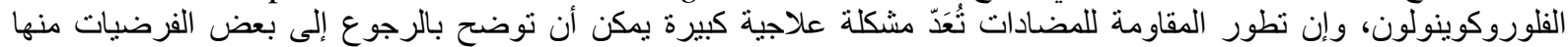
الاستخدام المفرط أو استخدام المضاد الحيوي غير الملائم (Sotto et al., 2001). 


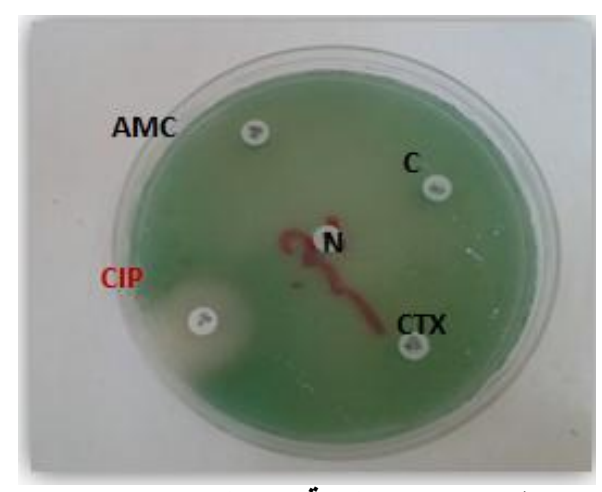

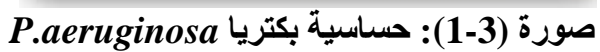

اللون الأحمر الحساسية للمضاد / اللون الأسود المقاومة للمضادياد.

التقدير الكمي للبايوسياتين المستخلص من

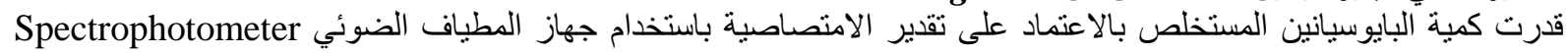
عند طول موجي 520nm. الصورة (4-3) توضح خطوات البن استخلاص وتنقية البايوسيانين.

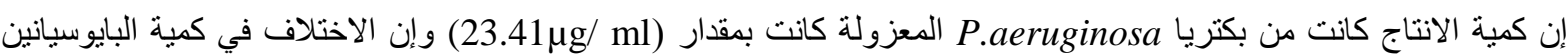

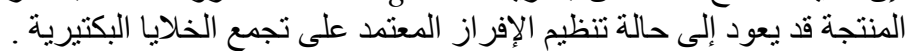

التركيز المثبط الأدنى (MIC) للبايوسياتين على أنواع بكتيرية مرضية:

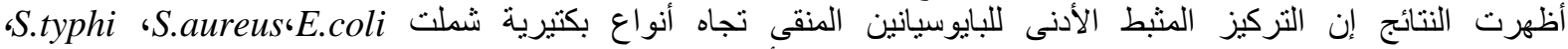
كان E.faecalis ، P.aeruginosa

فعالية البايوسيانين في التثبيط المايكروبي :

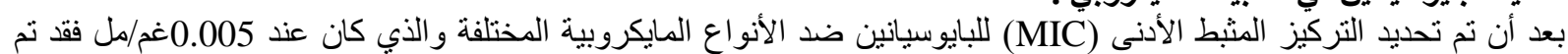

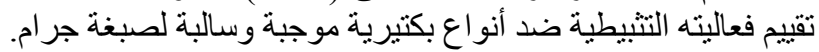

ومن ثم تم رفع تركيز البايوسيانين لملاحظة التثبيط بصورة أوضح على أطباق الأكار إذ أظهرت النتائج أن التركيز( 0.2 ) غم /مل من البايوسيانين

جدول 1-3: الفعالية التثيطية للبايو سيانين المنقى من P.aeruginosa مقدرةً بالملم

\begin{tabular}{|c|c|c|}
\hline الفعالية التثبيطية (بالملم) & الأنواع البكتيرية & 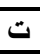 \\
\hline 25 & P.aeruginosa & 1 \\
\hline 21 & S.aureus & $\bar{r}$ \\
\hline 23 & E.faecalis & $r$ \\
\hline 22 & S.typhi & $\varepsilon$ \\
\hline 22 & E.coli & 0 \\
\hline
\end{tabular}

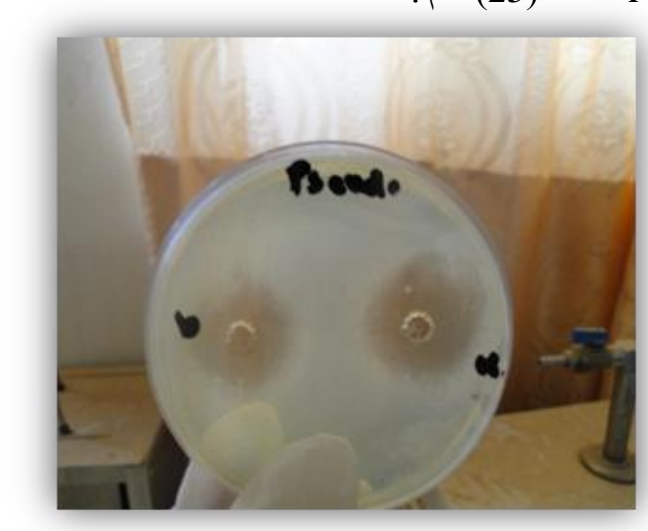

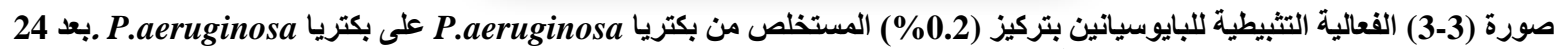

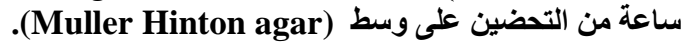

$$
\text { و على النوع S.aureus كانت (19) ملم كما في الصورة . }
$$




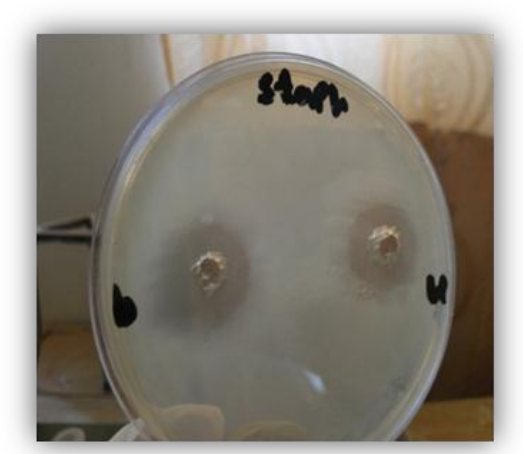

صورة (4-3) الفعالية التبيطية للبايوسيانين بتركيز (0.2\%) المستخلص من بكتريا P.aeruginosa على بكتريا S.aureus

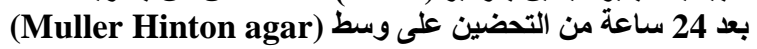

$$
\text { والنوع E.faecalis (23 ) كما في الصورة . }
$$

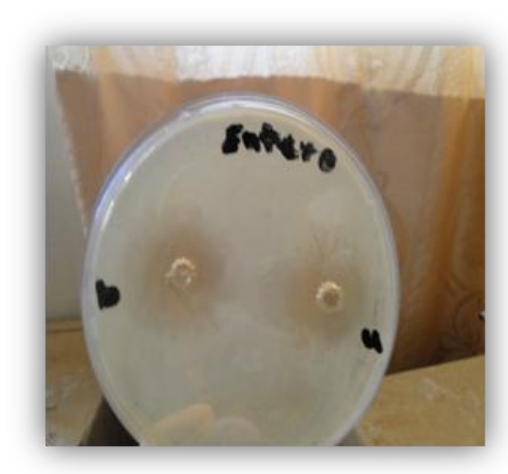

صورة (3-3) الفعالية التبيطية للبايوسياتين بتركيز (0.2\%) المستخلص من بكتريا P.aeruginosa على بكتريا E.faecalis ـ بعد 24 ساعة

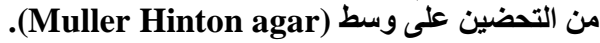

$$
\text { و النوع S.typhi كانت ( } 22 \text { ) ملم كما في الصورة . }
$$

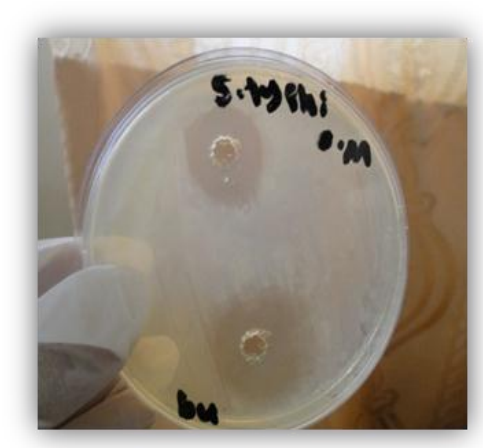

صورة (6-3) الفعالية التبيطية للبايوسيانين بتركيز (0.2\%) المستخلص من بكتريا P.aeruginosa على بكتريا S.typhi بعد 24 ساعة من

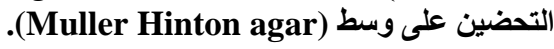

$$
\text { وبكتريا E.coli بأقطار تثبيطية (21) ملم. }
$$

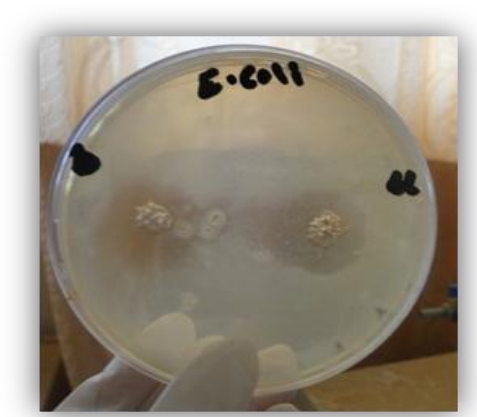

صورة (7-3) الفعالية التثيطية للبايوسيانين بتركيز (0.2\%) المستخلص من بكتريا P.aeruginosa على بكتريا E.coli بعد 24 ساعة من التحضين على وسط (Muller Hinton agar). 
وقد أظهرت النتائج ان اعلى فعالية تثبيطية للبايو سيانين كان على بكتريا P.aeruginosa حيث كان معدل التثبيط 25 ملم وهذا بدل

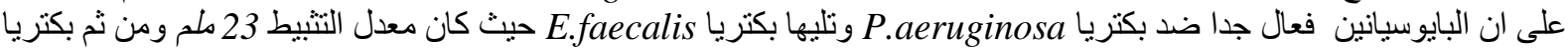
E.coli و S.typhi أظهرت انها اكثر مقاومة للبايوسيانين حيث كان معدل التثبيط 21 ملم.

البادئات المخصة Flavine 'Phenazine - specific methyltransferase، Phenazine biosynthetic operon) (containing Monooxygennase

استخدمت البادئات للتعبير عن انتاج البايوسيانين من بكتريا P.aeruginosa تبين التضاعف باستخدام تقنية PCR و الترحيل الكهربائي أدى الى ظهور حزم عند وزن جزيئي لكل من البادئات المخصصة عند Phenazine biosynthetic operon) بائين (Flavine containing Monooxygennase 'Phenazine - specific methyltransferase، و التي تشير الى قدرة النوع البكتيري p.aergenusa على انتاج البايوسيانين وان التفسير على انتاجه يكون من خلال جينات في

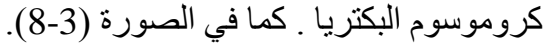

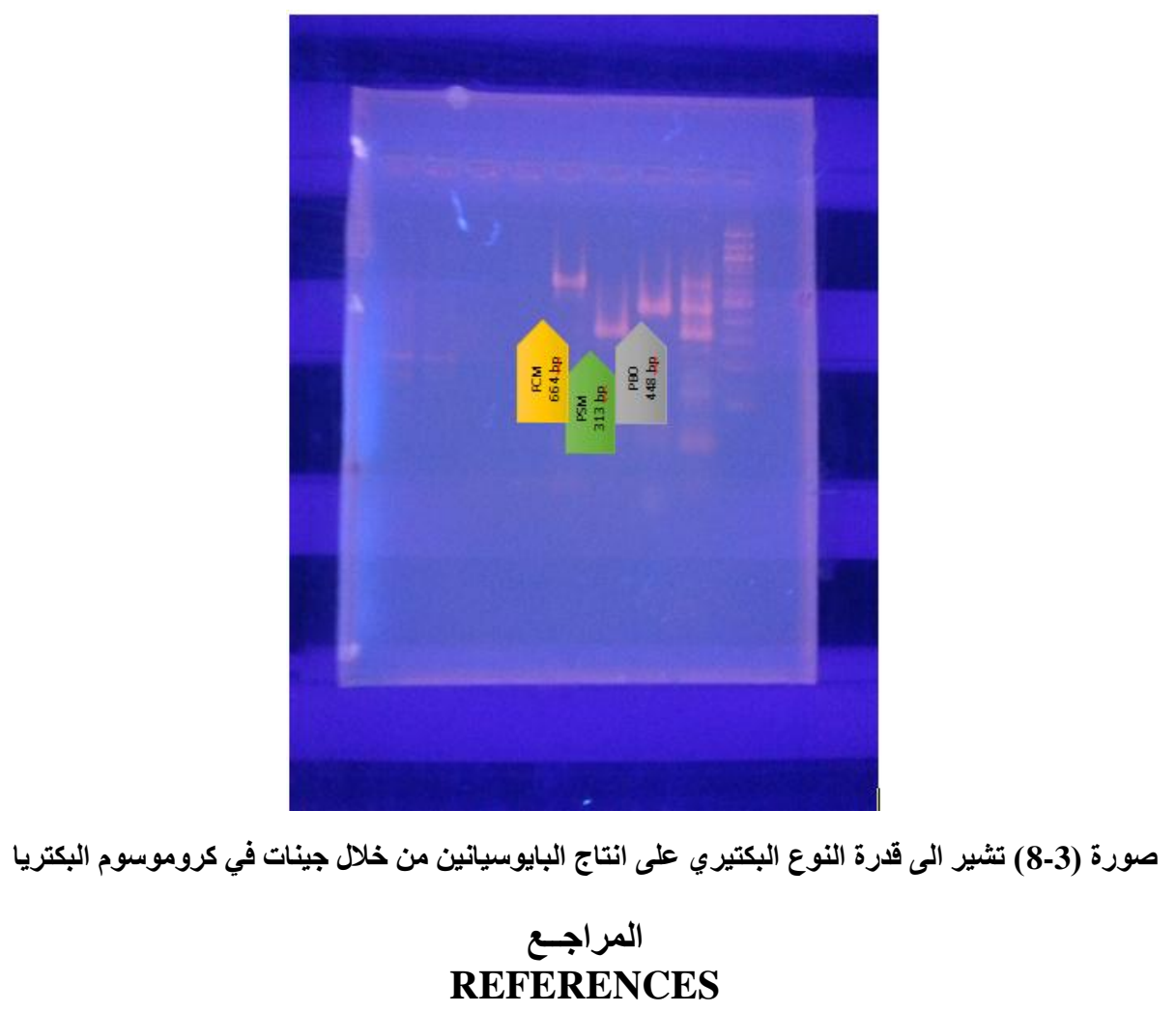

AOAC (Association Of Official Analytical Chemises) (2002): Official method of Analysis. $4^{\text {th }}$. ed. Assoc. Offic. Anal. Chem. Virginia. USA.

Balch, A. and Smith, R. (1994): Pseudomonas aeruginosa: Infections and Treatment. Informa Health Care. Pp. 83-84

Baron, EJ. and Finegold, SM. (1990): Baily and Scott`s Diagnostic Microbiology. $8^{\text {th }}$ ed. C.V. Mosby Co. USA.

CLSI (Clinical and Laboratory Standards Institute) (2006): Methods for dilution antimicrobial susceptibility tests for bacteria that grow aerobically; Approved standard. Seventh edition. Clinical and Laboratory Standard Institute Document, M7-A7, Wayne, Pennsylvania.

Collee, JG.; Fraser, GA.; Marmion, PB. and Simmons, A. (1996): Practical Medical Microbiology. $4^{\text {th }}$. Churchill Livingstone, New York.p.413-418.

Cowan and Steel's Manual for the Identification of Medical Bacteria (1993): $3^{\text {rd }}$ Edition. Ed. G. I. Barrow and R. K. A. Feltham.Cambridge University Press, Cambridge, New York.

Cruickshank, R.; Duguid, JP.; Marmion, BP. and Swain, RH. (1975): Medical Microbiology. $12^{\text {th }}$. New York. Churchill Livingstone.

Essar, DW.; Eberly, L.; Hadero, A. and Crawford, IP. (1990): Identifcation and Characterization of genes for second anthranilate synthase in Pseudomonas aeruginosa: interchangeability of the 
two anthranilate synthases and evolutionary implications. Journal of bacteriology. 172(2): 884900.

Greenwood, D.; Finch, R.; Davey, P. and Wilcox, M. (2007): Antimicrobial chemotherapy. Oxford University Press, New York.

Hassan, H.M. and Fridovich, I. (1980): Mechanism of the antibiotic action of pyocyanine. J. Bacteriol., 141: 156-163.

Holt, J.G.; Krieg, NR.; Sneath, PH.; Staley, JT. and Williams, ST. (1994): Bergy's manual of determinative bacteriology. $9^{\text {th }}$ ed. Williams, and Wilkins, USA.

Lyczak, JB.; Cannon, CL. and Pier, GB. (2000): Establishment of Pseudomonas aeruginosa infection: lessons from a versatile opportunist. Microbs Infect. 2: 1051-1060.

Mouget, JL.; Dakhama, A.; Lavoie, M. and de la Noue, J. (1995): Algal growth enhancement by bacteria: is consumption of photosynthetic oxygen involved.?FEMS Microbiology Ecology. 18: $35-44$.

NCCLS (National Committee for Clinical Laboratory Standards) (2002): Performance standards for antimicrobial susceptibility testing; twelfth informational supplement. M100-S12, NCCLS, Pennsylvania.

Prescott, LM.; Harley, JP. and Klein, DA. (2005): Microbiology. $6^{\text {th }}$ ed. McGraw. Hill companies Inc. New York.

Saha, S.; Thavas, $R$. and Jayalakshmi, S. (2008): Phenazine Pigments from Pseudomonas aeruginosa and their application as antibacterial agent and food colourants. Research J.Microbiol. 3(3): $122-128$.

Sotto, A.; de Boever, CM.; Fabbro-Peray, P.; Gouby, A.; Sirot, D. and Joudan, J. (2001): Risk factors for antibiotic resistant Escherichia coli isolated from hospitalized patients with Urinary Tract Infection: a Prospective study. J. Clinical Microbiol. 39: 438-444.

Todar, K. (2004): Pseudomonas and related bacteria. Todar's Online Textbook of Bacteriology. Available online at: http://textbookofbacteriology.net/pseudomonas.html. Accessed 5th July 2006.

Willey, JM.; Sherwood, LM.andWoolverton, CJ. (2008): Prescott, Harley and Klein's Microbiology, $7^{\text {th }}$ Ed., McGraw-Hill Company, Inc., USA. pp. 